\title{
FACTORS AFFECTING THE FINANCIAL PERFORMANCE OF THE FIRMS DURING THE FINANCIAL CRISIS: EVIDENCE FROM TURKEY
}

\section{H.Gökçehan DEMIRHAN ${ }^{1}$ Waseem Anwar ${ }^{2}$}

\begin{abstract}
s
This study investigates the factors that affect the firm performance during the international financial crisis which also affected Turkish economy. Sample of 140 non-financial firms from Borsa Istanbul has been investigated for the financial crisis period of 2008. Market-to-book ratio has been taken as the measure of performance in the study whereas eleven financial ratios have been taken as independent variables. A factor analysis has been applied on independent variables and categorized them into four categories. Then multiple regression analysis has been applied by taking the factor scores of our four factors. Results of the study suggest that liquidity of the firm affects the firm's market value positively whereas high leverage inversely affects the firm performance during crisis.
\end{abstract}

Key words: financial performance, crisis, turkey.

\section{Introduction:}

Determinants of corporate performance are under consideration of investigation since the evolution of modern firm. From financial point of view the ultimate goal of a firm is to maximize the stockholders' wealth and firm performance is one of the most important factorswhich helps to maximize the shareholder wealth. For this reason, firm performance is among the most important research considerations of financial management. Factors those have important effects on determination of firm performance could be divided into micro and macro factors. Micro factors include the internal factors, whereas macro factors include the factors from external environment. Any change in the macro factors in the economy affects the firms which could be seen in the performance of the firm as well.These affects could be positive or negative depending on the change in the macro environment and structure of the firm. Even the same change in the macro environment may or may not

\footnotetext{
${ }^{1}$ Ph.D.Candidate Dokuz Eylul University, ${ }^{2} \mathbf{P h}$.D.Candidate Dokuz Eylul University
} 
has the same impact on the two firms which belongs to the same industry(Wei \& Zhang, 2008). There could be number of reasons for this difference in response of the firms to the same macro changes but all of these reasons are related to the micro factors of the firm. This study will not cover all of those characteristics but just those that are related to the financial management will be covered.Economic crisis is the extreme economic condition so in this study our focus is on the firm performance during the crisis. As the major goal of the firm to maximize the stockholders wealth, so-we will judge the performance on the bases of value of the firm. Sample of the study includes 140 manufacturing firms listed in Borsa Istanbul during the recent financial crisis. Thousands of firms across the countries reported billions of dollars of losses during the recent financial crisis that has started in USA and then hurt number of countries. Turkey has also experienced this crisis in 2008. So our observation period would cover the data of 2008 when the effects of the crisis were most sharply felt by the firms. Ultimate goal of a corporation is to increase the value of the firm, by keeping in view this consideration, market to book ratio has been used as the dependent variable in this study. In order to minimize our independent variables, a factor analysis has been applied on different financial ratios. These financial ratios showed their loading on four independent factors and then those four factors have been used for the further analysis in the study. After this a multiple regression has been applied by taking the scores of these factors as the independent variable.

\section{Literature Review:}

Beaver (1966) investigated the firm's bankruptcy and argued that failure of the firm could be predicted on the bases of financial ratio analysis. He made a univariate analysis in which he took a sample of 79 failed firms and 79 survived firms and compare them by applying the paired sample technique. Total of 30 financial ratios have been used in that study. Study concludes that six financial ratios significantly explain the success/ failure of the firm.LoPucki (1983)also investigated the factors that vary between failed and non-failed firms. He concluded that financial indicators significantly vary between failed and non-failed firms.Altman (1968) done a discriminant analysis between bankrupt and non-bankrupt firms. For analysis purpose he took all the firms that filed for bankruptcy during 1964-65. He took five types of ratios that includes liquidity, profitability, solvency, leverage and activity ratios. Total of 22 ratios have been used in the analysis portion. This study concluded that bankrupt firms were different from other firms in respect to number of financial ratios. 
Ege Strategic Research Journal

Kaveri (1980) addressed the same question by asking if it is possible that financial health of the firm could be judged with the help of few financial ratios The positive attribute of this study was that it does not make a univariate analysis but it took different states of firms. He categorized the firms into four categories; good, near to good, not so bad and bad. Multivariate discriminant analysis has been used in this study by taking 22 financial ratios. Sample of the study includes 520 small firms from different sectors of India. In the discriminants analysis different combination of the ratios have been examined and significance has been tested. Then in the final model five variables have been included on the bases of maximum significance and prediction power.Altman and Sametz (1977) reexamine the same model that was developed by Altman (1968), they have taken the firms that became bankrupt during the period of 1970-1973. In the previous study of Altman (1968), 5\% of the firms were misclassified but this time ratio of misclassified firms has been increased to $18 \%$.

Ohlson (1980) considered a large sample of 105 bankrupt and 2058 non bankrupt firms from US and used logit model to predict the bankruptcy on the bases of financial indicators. According to the results of the study, bankruptcy of the firm could be predicted by the financial statement of the firm. The most important indicators include size, leverage, profitability and liquidity. In his dissertation, Blum (1974) made a discriminant model to find the difference between failed and non-failed firms.In his sample he took a paired sample of 115 failed and 115 non-failed firms. 12 ratios have been used in this study and he got an accuracy rate of $93 \%$ to $95 \%$. When the model was used to predict the three year to bankruptcy then accuracy had been decreased to $83 \%$.Sulairnan, Jili, and Sanda (2001) investigated the corporate failure in Malaysia. They have developed a logit model and investigated the factor that could be used to predict the failure. Various financial ratios have been used in the study but three main ratios were found to have a significant prediction power. These ratios include leverage, interest coverage and total assets turnover. Another Malaysian study by Abdullah and Ahmad (2008) compared the different methodologies for failure prediction. They concluded that out of ten determinants of corporate performance studied, leverage, net income growth and return on assets are found to have the significant power to predict the failure of the firm.Storey, Keasey, Wynarczyk, and Watson (1987) examined the sample of 636 manufacturing firms from United Kingdom. They found the financial ratios that matters in the survival of the firms. Ownership, management structure, accounting procedures, and financing of the firms have been investigated. Results of the study confirm that financial ratios have significant power of failure prediction. 


\section{METHODOLOGY}

The aim of the study is to discover the factors that affect the financial performance of manufacturing firms listed in Borsa Istanbul during the recent financial crisis. Recent financial crisis has started in USA and then spread out most of the other countries by the collapse of major financial institutions as Lehman Brothers in 2008. Therefore the analysis period of this study covers 2008 .

As mentioned before, the ultimate aim of the firm should be maximizing the firm value. So, in the scope of this analysis market-to-book ratio is regarded as the variable representing financial performance. There are several factors which have influence on the financial performance of the firm and these factors can be grouped as firmspecific factors and macro factors. The focus of this study is on firm-specific factors which can be represented by financial ratios. Financial ratios data are used in many areas in accounting and finance research. Predictive power of financial ratios are mainly tested in bankruptcy prediction (Altman, 1968; Poston, Harmon \&Gramlich, 2011), however there are also studies investigating the relationship between financial ratios and stock returns (Lewellen, 2002). This study extends these analyses by testing whether financial ratios have any effects on market values of firms during the crisis period. For this purpose, first of all, factor analysis will be used to group the financial ratios into factors and then the factor scores calculated in this analysis will be used as independent variables in a multiple regression analysis. The dependent variable in multiple regression analysis is market-tobook ratios of firms under interest.

\section{Sample\&Data}

The sample of the study includes the firms in the manufacturing industry of Borsa Istanbul. 140 firms, of which the financial data have been reached without any problem, are selected in sample group. Market-to-book ratios are taken from annual bulletin of Borsa Istanbul. Financial ratios are calculated by the authors using the balance sheet and income statement information of sample firms. Balance sheet and income statement of the sample firms are downloaded from the website of Borsa Istanbul.

\section{Factor Analysis}

In finance literature there are numerous financial ratios which are used to evaluate the financial soundness of the firms. These ratios are grouped into several categories. For example current ratio, acid-test ratio, cash ratio etc. are in liquidity ratios category which give information about the short-term solvency of a firm. All of these ratios 
in different categories can have important effects on the financial performance of a firm, but taking all these ratios as independent variables in an empirical research can cause severe problems such as multicollinearity. Thus, factor analysis has been used by researchers as a mean of eliminating redundancy and reducing the number of financial ratios needed for empirical research (De, Bandyopadhyay, \& Chakraborty, 2011).

Factor analysis is a technique that can be utilized to examine the underlying patterns or relationships for a large number of variables. By using factor analysis we can determine whether the information can be condensed or summarized in a smaller set of factors or components (Hair, Black, Babin, \& Anderson, 2011). In this study the following financial ratio variables are used in a confirmatory factor analysis to be able to group them into categories:

\begin{tabular}{|l|l|}
\hline Financial Ratio & Definition \\
\hline Current Ratio (Current) & Current Assets / Current Liabilities \\
\hline Acid-test Ratio (Acid) & (Current Assets - Inventory)/Current Liabilities \\
\hline Inventory Turnover (IT) & Cost of Goods Sold/ Inventory \\
\hline Accounts Receivables Turnover (RT) & Net Sales/Accounts Receivables \\
\hline Total Asset Turnover (TAT) & Net Sales/ Total Assets \\
\hline Debt-to-Equity (DE) & Total Liabilities/ Total Equity \\
\hline Financial Leverage Ratio (LEV) & Total Liabilities/Total Assets \\
\hline Net Profit Margin (NPM) & Net Profit/Net Sales \\
\hline Operating Profit Margin (OPM) & Operating Profit/Net Sales \\
\hline Return on Assets (ROA) & Net Profit/ Total Assets \\
\hline Return on Equity (ROE) & Net Profit / Total Equity \\
\hline
\end{tabular}

Table 1: Variables in Factor Analysis

After conducting factor analysis, factor scores extracted from this analysis are used in multiple discriminant analysis.

\section{Multiple Regression Analysis}


Multiple regression analysis assesses the degree and character of relationships between a dependent variable and independent variables in an objective way. As a result of the analysis, estimated regression coefficients indicate the relative importance of each independent variable in the prediction of the dependent variable. They show how much increase of one unit in the independent variable would affect the dependent variable, assuming that all the other independent variables remain unchanged (Sekaran \& Bougie, 2010). Multiple regression can be conducted by three different types of data: cross sectional, time series and panel. A cross-sectional data consists of a sample of individuals, households, firms or a variety of other units, at a given point in time. A time series data consist of observations on a variable or several variables over time such as stock prices, money supply, gross domestic product etc. A panel data set (or longitudinal data) consists of a time series for each cross-sectional member in a data set (Wooldridge, 2012). Cross-sectional data is used in this study because market value and financial ratio data of 2008 are used in the analysis.

\section{Dependent Variable:}

In this study, the aim is to investigate whether financial ratios have any effect on firms' market values. Therefore market-to-book ratio is used as a dependent variable.

Market-to-book Ratio = Market Value of Equity/ Book Value of Equity

\section{Independent Variables:}

Independent variables used in the multiple regression analysis are the factor scores that will be calculated in factor analysis of financial ratios.

\section{Model:}

The model that is tested in multiple regression analysis is as follows:

$\mathrm{MTB}_{\mathrm{i}}=\alpha+\beta_{\mathrm{j}} \mathbf{F}_{\mathbf{j}}+\varepsilon$

where

MTB $_{\mathrm{I}}=$ Market-to-book ratio of firm i

$\alpha=$ intercept,

$F_{j}=$ Factor score of $j^{\text {th }}$ factor

$\beta_{\mathrm{j}}=$ coefficient,

$\varepsilon=$ error term 


\section{FINDINGS}

\section{Findings of Factor Analysis}

Financial ratios which are reported in Table 1 are used in confirmatory factor analysis. At first run the 11 financial ratios of 140 firms for year 2008 are put into analysis the test statistics for K-M-O and Barlett Test for the first run are as follows:

\begin{tabular}{|l|l|}
\hline Kaiser-Meyer-Olkin Measure of Sampling Adequacy. & 0,537 \\
\hline Bartlett's Test of Sphericity & Approx. Chi-Square: 869 \\
& sig.:0,000 \\
\hline
\end{tabular}

Table 2: KMO and Bartlett's Test for 1st Factor Analysis

KMO test shows whether sampling is adequate for factor analysis or not. KMO statistics equal to or bigger than 0,50 means that the sample is adequate for factor analysis. In first run of factor analysis we see that the sample is appropriate for factor analysis and Barlett's test also supports it.

In factor analysis there can be some variables that are not adequately accounted for by the factor solution. One common approach to identify these variables is examining each variable's communality which represents the amount of variance accounted for by the factor solution for each variable. The guideline used here is to eliminate the variables with communality less than 0,50 and run the factor analysis again. In the first run the communalities for variables are as follows:

\begin{tabular}{|l|l|l|}
\hline & Initial & Extraction \\
\hline Current & 1,000 & 0,912 \\
\hline Acid & 1,000 & 0,930 \\
\hline IT & 1,000 & 0,661 \\
\hline RT & 1,000 & 0,552 \\
\hline TAT & 1,000 & 0,659 \\
\hline
\end{tabular}




\begin{tabular}{|l|l|l|}
\hline DE & 1,000 & 0,892 \\
\hline NPM & 1,000 & 0,720 \\
\hline OPM & 1,000 & 0,835 \\
\hline ROE & 1,000 & 0,905 \\
\hline LEV & $\mathbf{1 , 0 0 0}$ & $\mathbf{0 , 3 7 5}$ \\
\hline ROA & 1,000 & 0,582 \\
\hline
\end{tabular}

Table 3: Communalities for 1st Factor Analysis

Extraction Method: Principal Component Analysis

The communality of variable LEV (Total Liabilities/ Total Assets) is 0,375 which is smaller than 0,50 . Therefore this variable is excluded and factor analysis is run again with 10 financial ratios second time. KMO statistics and Barlett's test as reported in Table 4 show again that the sample is appropriate for factor analysis.

\begin{tabular}{|l|l|}
\hline Kaiser-Meyer-Olkin Measure of Sampling Adequacy. & 0,534 \\
\hline Bartlett's Test of Sphericity & Approx. Chi-Square: 828 \\
& df:45; sig.:0,000 \\
\hline
\end{tabular}

Table 4: KMO and Bartlett's Test for 2nd Factor Analysis

Communalities of all variables are over 0,50 which are reported at Table 5 .

\begin{tabular}{|l|l|l|}
\hline & Initial & Extraction \\
\hline Current & 1,000 &, 931 \\
\hline Acid & 1,000 &, 966 \\
\hline IT & 1,000 &, 672 \\
\hline RT & 1,000 &, 528 \\
\hline TAT & 1,000 &, 699 \\
\hline
\end{tabular}




\begin{tabular}{|l|l|l|}
\hline DE & 1,000 &, 895 \\
\hline NPM & 1,000 &, 736 \\
\hline OPM & 1,000 &, 837 \\
\hline ROE & 1,000 &, 906 \\
\hline ROA & 1,000 &, 587 \\
\hline
\end{tabular}

Table 5: Communalities for 2nd Factor Analysis

Extraction Method: Principal Component Analysis

As a rotation method Varimax is used the rotated component matrix is reported below:

\begin{tabular}{|c|c|c|c|c|}
\hline & \multicolumn{4}{|c|}{ Component } \\
\hline & 1 & 2 & 3 & 4 \\
\hline Acid & ,979 &, 041 &, 020 &, 076 \\
\hline Current & ,955 &, 081 &,- 048 &, 098 \\
\hline OPM & ,069 & ,906 &,- 083 &, 066 \\
\hline ROA &,- 047 &, 727 &, 193 &, 135 \\
\hline NPM &, 531 &, 668 &, 084 &, 029 \\
\hline TAT &,- 166 &, 126 &, 810 &, 004 \\
\hline IT & ,201 &,- 138 &, 782 &,- 026 \\
\hline RT &,- 024 &, 148 &, 706 &, 080 \\
\hline ROE & ,061 &, 112 &, 050 & ,942 \\
\hline $\mathrm{DE}$ &,- 102 &,- 089 &,- 012 &,- 936 \\
\hline
\end{tabular}

Table 6: Rotated Component Matrix

Table 6 reveals that 4 factors are extracted as result of principal component analysis. Total variance explained by each of these four factors are shown in Table 7: 


\begin{tabular}{|c|c|c|c|c|c|c|c|c|c|}
\hline \multirow[b]{2}{*}{ Component } & \multicolumn{3}{|c|}{ Initial Eigenvalues } & \multicolumn{3}{|c|}{$\begin{array}{l}\text { Extraction Sums of Squared } \\
\text { Loadings }\end{array}$} & \multicolumn{3}{|c|}{$\begin{array}{llll}\text { Rotation Sums of Squared } \\
\text { Loadings } & & & \\
\end{array}$} \\
\hline & Total & $\begin{array}{l}\% \text { of } \\
\text { Variance }\end{array}$ & $\begin{array}{l}\text { Cumulative } \\
\%\end{array}$ & Total & $\begin{array}{l}\% \text { of } \\
\text { Variance }\end{array}$ & $\begin{array}{l}\text { Cumulative } \\
\%\end{array}$ & Total & $\begin{array}{l}\% \text { of } \\
\text { Variance }\end{array}$ & $\begin{array}{l}\text { Cumulative } \\
\%\end{array}$ \\
\hline 1 & 2,839 & 28,395 & 28,395 & 2,839 & 28,395 & 28,395 & 2,242 & 22,416 & 22,416 \\
\hline 2 & 1,905 & 19,055 & 47,449 & 1,905 & 19,055 & 47,449 & 1,882 & 18,822 & 41,238 \\
\hline 3 & 1,600 & 15,997 & 63,446 & 1,600 & 15,997 & 63,446 & 1,824 & 18,237 & 59,475 \\
\hline 4 & 1,412 & 14,122 & 77,568 & 1,412 & 14,122 & 77,568 & 1,809 & 18,093 & 77,568 \\
\hline 5 &, 751 & 7,512 & 85,080 & & & & & & \\
\hline 6 &, 612 & 6,120 & 91,200 & & & & & & \\
\hline 7 &, 444 & 4,443 & 95,644 & & & & & & \\
\hline 8 & 228 & 2,283 & 97,927 & & & & & & \\
\hline 9 &, 187 & 1,871 & 99,798 & & & & & & \\
\hline 10 &, 020 & ,202 & 100,000 & & & & & & \\
\hline
\end{tabular}




\begin{tabular}{|c|c|c|c|c|c|c|c|c|c|}
\hline \multirow[b]{2}{*}{ Component } & \multicolumn{3}{|c|}{ Initial Eigenvalues } & \multicolumn{3}{|c|}{$\begin{array}{l}\text { Extraction Sums of Squared } \\
\text { Loadings }\end{array}$} & \multicolumn{3}{|c|}{$\begin{array}{l}\text { Rotation Sums of Squared } \\
\text { Loadings }\end{array}$} \\
\hline & Total & $\begin{array}{l}\% \text { of } \\
\text { Variance }\end{array}$ & $\begin{array}{l}\text { Cumulative } \\
\%\end{array}$ & Total & $\begin{array}{l}\% \text { of } \\
\text { Variance }\end{array}$ & $\begin{array}{l}\text { Cumulative } \\
\%\end{array}$ & Total & $\begin{array}{l}\% \text { of } \\
\text { Variance }\end{array}$ & $\begin{array}{l}\text { Cumulative } \\
\%\end{array}$ \\
\hline 1 & 2,839 & 28,395 & 28,395 & 2,839 & 28,395 & 28,395 & 2,242 & 22,416 & 22,416 \\
\hline 2 & 1,905 & 19,055 & 47,449 & 1,905 & 19,055 & 47,449 & 1,882 & 18,822 & 41,238 \\
\hline 3 & 1,600 & 15,997 & 63,446 & 1,600 & 15,997 & 63,446 & 1,824 & 18,237 & 59,475 \\
\hline 4 & 1,412 & 14,122 & 77,568 & 1,412 & 14,122 & 77,568 & 1,809 & 18,093 & 77,568 \\
\hline 5 &, 751 & 7,512 & 85,080 & & & & & & \\
\hline 6 &, 612 & 6,120 & 91,200 & & & & & & \\
\hline 7 &, 444 & 4,443 & 95,644 & & & & & & \\
\hline 8 &, 228 & 2,283 & 97,927 & & & & & & \\
\hline 9 &, 187 & 1,871 & 99,798 & & & & & & \\
\hline
\end{tabular}


We can understand from Table 7 that approximately $78 \%$ of total variance can be explained by four factors. The variables under each factor are as follows:

\begin{tabular}{|l|l|l|l|}
\hline Factor 1 & Factor 2 & Factor 3 & Factor 4 \\
\hline Current Ratio & Net Profit Margin & Inventory Turnover & Return on Equity \\
Acid-test Ratio & Operating Profit Margin & Acc. Receivables Turnover & Debt-to-Equity \\
& Return on Assets & Total Asset Turnover & \\
\hline
\end{tabular}

Table 8: Factors

As a result of the principal component analysis we had ratio categories supporting the finance literature. Current Ratio and Acid-test Ratios are grouped into factor 1. Both of these ratios give information about the short-term debt paying ability of the firm, so we can name this factor as "Liquidity". Net Profit Margin, Operating Profit Margin and Return on Assets are categorized under factor 2. These ratios are the indicators of the firm's profitability, thus it would be appropriate to name this factor as "Profitability". The third factor's variables are Inventory Turnover, Accounts Receivables Turnover and Total Asset Turnover, all of which show the asset management efficiency. Therefore the $3^{\text {rd }}$ factor can be named as "Asset Management Efficiency". The fourth and the last factor have Return on Equity and Debt-to-Equity. These two variables are associated with financial leverage concept. Financial leverage is about the extent to which a firm uses debt financing. Return on Equity of a firm are magnified, or "leveraged," when the firm earns more on investments financed with borrowed funds than it pays in interest (Brigham \& Houston, 2012). Thus debt-to-equity ratio and return on equity are closely related. As a result, we can name the fourth factor as "Financial Leverage". The names given to four factors are summarized at Table 9.

\begin{tabular}{|l|l|}
\hline Factor & Name \\
\hline Factor 1 & Liquidity \\
\hline Factor 2 & Profitability \\
\hline Factor 3 & Asset Management Efficiency \\
\hline Factor 4 & Financial Leverage \\
\hline
\end{tabular}


Table 9: Name of the Factors

Next, factor scores for all of the four factors mentioned above are used in multiple regression analysis as independent variables.

\section{Findings of Multiple Regression Analysis}

Model summary after running the multiple regression analysis with the before mentioned dependent variable and independent variables are reported at Table 10.

\begin{tabular}{|l|l|l|l|l|}
\hline Model & $\mathbf{R}$ & $\mathbf{R}^{2}$ & Adjusted $\mathbf{R}^{\mathbf{2}}$ & $\begin{array}{l}\text { Std. Error of the } \\
\text { Estimate }\end{array}$ \\
\hline 1 & $65,7 \%$ & $43,2 \%$ & $41,5 \%$ & 1,139 \\
\hline
\end{tabular}

Table 10: Model Summary for Multiple Regression Analysis

As Table 10 reveals, the independent variables used in the model explains $41,5 \%$ of variance observed in dependent variable. The statistics about the Analysis of Variance of the model is given at below table and according to these findings model is significant at $99 \%$ confidence level.

\begin{tabular}{|l|l|l|l|l|l|l|}
\hline \multicolumn{2}{|l|}{ Model } & Sum of Squares & df & Mean Square & F & Sig. \\
\hline 1 & Regression & 133,161 & 4 & 33,290 & 25,659 &, 000 \\
\cline { 2 - 5 } & Residual & 175,153 & 135 & 1,297 & & \\
\cline { 2 - 5 } & Total & 308,314 & 139 & & & \\
\hline
\end{tabular}

Table 12 shows the significance level and the value of coefficients for independent variables together with the collinearity statistics.

\begin{tabular}{|c|c|c|c|c|c|c|c|c|}
\hline \multirow{2}{*}{\multicolumn{2}{|c|}{ Model }} & \multicolumn{2}{|c|}{$\begin{array}{l}\text { Unstandardized } \\
\text { Coefficients }\end{array}$} & \multirow{2}{*}{\begin{tabular}{|l} 
Standardized \\
Coefficients \\
Beta
\end{tabular}} & \multirow[b]{2}{*}{$\mathbf{t}$} & \multirow[b]{2}{*}{ Sig. } & \multicolumn{2}{|c|}{$\begin{array}{l}\text { Collinearity } \\
\text { Statistics }\end{array}$} \\
\hline & & B & $\begin{array}{l}\text { Std. } \\
\text { Error }\end{array}$ & & & & Tolerance & VIF \\
\hline 1 & Constant &, 795 &, 096 & & 8,263 &, 000 & & \\
\hline
\end{tabular}




\begin{tabular}{|l|l|l|l|l|l|l|l|l|}
\hline Liquidity & $\mathbf{, 2 2 3}$ & $\mathbf{, 0 9 7}$ & $\mathbf{, 1 5 0}$ & $\mathbf{2 , 3 1 3}$ & $\mathbf{, 0 2 2}$ & 1,000 & 1,000 \\
\hline Profitability &, 062 &, 097 &, 042 &, 645 &, 520 & 1,000 & 1,000 \\
\hline $\begin{array}{l}\text { Asset Management } \\
\text { Efficiency }\end{array}$ &, 041 &, 097 &, 028 &, 426 &, 671 & 1,000 & 1,000 \\
\hline Financial Leverage & $\mathbf{- , 9 5 0}$ & $\mathbf{, 0 9 7}$ & $\mathbf{- , 6 3 8}$ & $\mathbf{- 9 , 8 3 3}$ & $\mathbf{, 0 0 0}$ & 1,000 & 1,000 \\
\hline
\end{tabular}

Table 12: Coefficients Table

First of all there is no multicollinearity problem because VIF values are equal to 1 for tolerance level of 1 . According to the findings two variables have statistically significant coefficients: Liquidity \& Financial Leverage. The coefficient of liquidity has a positive sign which means that firms with higher liquidity has higher market-to-book ratios. However the sign of the coefficient of Financial Leverage variable is positive, meaning that firms with higher financial leverage have lower market-to-book ratios or vice versa.

As a result, the regression model is estimated as follows:

$\mathrm{MTB}=0,795+0,223$ (Liquidity)- 0,950 (Financial Leverage $)+\varepsilon$

\section{SUMMARY AND CONCLUSIONS:}


Financial performance of the Turkish firms has been analyzed in this study during the world financial crisis of 2008. During the financial crisis thousands of the firms around the globe experienced high losses and even some of them cease to exist. This financial crisis started from US and hit a large number of developed and developing countries. Turkish economy has also experienced this financial crisis; this is the influential factor to conduct this study. Sample of 140 non-financial firms from Borsa Istanbul has been investigated for the financial crisis period of 2008. Market-to-book ratio has been taken as the measure of performance in the study whereas ten financial ratios have been taken as independent variables. Although there is a conceptual categorization of financial ratios that has been used in previous studies, in this study we have conducted a factor analysis for categorization. Factor analysis successfully grouped all of our independent variables (financial ratios) into four categories. After factor analysis, these four factors have been taken as independent variables and their scores have been treated as values of variables. Then multiple regression analysis has been applied by taking the market to book ratio as dependent variable and four factors as independent variables. Results suggest that liquidity of the firm affects the firm's market value positively. Firms with good liquidity performed better during crises period. High leverage inversely found to be inversely correlated with firm performance during crisis period which indicate that firms with high leverage faced lots of trouble during crisis.

One of the most important results of the study is, it could be suggested that managers should concentrate on the liquidity position of the firm in order to avoid financial distress during crisis period. Managing a reasonable amount of debt in capital structure should be another consideration for the finance managers.

\section{References:}

Abdullah, N. A. H., \& Ahmad, A. H. (2008). Predicting corporate failure of Malaysians listed companies: Comparing multiple discriminant analysis, logistic regression and the hazard model. International Research Journal of Finance and Economics(15), 201-217.

Altman, E. I. (1968). Financial ratios, discriminant analysis and the prediction of corporate bankruptcy. The journal of finance, 23(4), 589-609.

Altman, E. I., \& Sametz, A. W. (1977). Financial crises: Institutions and markets in a fragile environment: John Wiley \& Sons.

Beaver, W. H. (1966). Financial ratios as predictors of failure. Journal of accounting research, 71-111.

Blum, M. P. (1974). Failing Company Doctrine, The. BC Indus. \& Com. L. Rev., 16, 75.

Brigham, E. F., \& Houston, J. F. (2012). Fundamentals of Financial Management (7. b.). Mason: Southwestern Cengage Learning.

De, A., Bandyopadhyay, G., \& Chakraborty, B. (2011). Application of the Factor Analysis on the Financial Ratios and Validation of the Results by the Cluster Analysis: An Empirical Study on the Indian Cement Industry. Journal of Business Studies Quarterly, 2(3), 13-31.

Hair, J. F., Black, W. C., Babin, B. J., \& Anderson, R. E. (2011). Multivariate Data Analysis. 
Kaveri, V. (1980). Financial Ratios as Predictors of Borrowers' Health: With Reference to Small-scale Industries in India: Sultan.

Lewellen, J. (2002). Predicting Returns with Financial Ratios. MIT Sloan Working Paper No. 4374-02

LoPucki, L. M. (1983). Debtor in Full Control--Systems Failure under Chapter 11 of the Bankruptcy Code, The. Am. Bankr. LJ, 57, 99.

Ohlson, J. A. (1980). Financial ratios and the probabilistic prediction of bankruptcy. Journal of accounting research, 109-131.

Poston, K.M., Harmon, W.K., \& Gramlich J.D. (2011). A Test of Fİnancial Ratios AS Predictors of Turnaround versus Failure Among Financially Distressed Firms, Journal of Applied Business Research, 10(1), 41-56

Sekaran, U., \& Bougie, R. (2010). Research Methods for Business: A Skill Building Approach. Wiley\&Sons Publication.

Storey, D. J., Keasey, K., Wynarczyk, P., \& Watson, R. (1987). The performance of small firms: Profits, jobs and failures. University of Illinois at Urbana-Champaign's Academy for Entrepreneurial Leadership Historical Research Reference in Entrepreneurship.

Sulairnan, M., Jili, A., \& Sanda, A. U. (2001). Predicting corporate failure in Malaysia: An application of the Logit Model to financial ratio analysis.

Wei, K., \& Zhang, Y. (2008). Ownership structure, cash flow, and capital investment: Evidence from East Asian economies before the financial crisis. Journal of Corporate Finance, 14(2), 118-132.

Wooldridge, J. M. (2012). Introductory Econometrics: A Modern Approach. Cengage Learning. 